\title{
Evaluation of Bill Gate's panacea for development and poverty reduction in Nigeria through improving agriculture
}

\author{
Dr. Charles 0. Okwuwa \\ Department of Sociology \\ Ibrahim Badamasi Babangida University, Lapai \\ Niger Sate, Nigeria.
}

\begin{abstract}
Through successive military and civilian regimes, Nigeria devised laudable but often duplicated agriculture focused policies and programmes targeting poverty reduction, its observed inter-generational plague. Well managed technology driven agriculture prefigures food security, improved national revenue profile, industrialization catalyst, high level employment, low level poverty, national development and social order, socio-economic indicators that are so far absent. This observational research aims at evaluating government's efforts towards solving poverty and related problems through the lens of empowered local farmer focus and inclusive agriculture, a Bill Gates antidote. It employed official records and statistics and related secondary data. Among the findings are availability of right policies and programmes but with generally low matchup on agricultural promotion inputs, including low budgets, rural-urban and gender based financial exclusiveness, irrigation and extension services for farmer empowerment. Set targets in many critical domains were unmet with resultant low food security (availability and nutrition), increasing poverty and employment. There exists a weak 2018 economy which is marginally improving, since 2016. The fragility progressively continues reproducing more poverty and social tension manifest in conflicts, kidnappings and political thuggery. Extant data suggest that quality of life in Nigeria is low and lacks the utilitarian philosophy. Nigeria emerged as the 2018 world poverty capital highest ever unemployment figure $(23 \%)$ and among the eight hungriest globally. Foremost, political will to execute inclusive policies and programmes, is needed. Improved agricultural budget, financial inclusiveness in ruralurban, gender resource allocation, irrigation and extension services are key needs.
\end{abstract}

Key words: Poverty, inclusiveness, funding, inputs, food security

\section{INTRODUCTION}

Poverty has assumed a frightening proportion globally and it is now discussed as a tragedy. The United Nations 2030 Agenda for Sustainable Development has Goal 2 as: End hunger, achieve food security and improved nutrition and promote sustainable agriculture. Aimed at 'Transforming our World', the agenda demands "All countries and all stakeholders, acting in collaborative partnership must implement this plan". We are resolved to free the human race from the tyranny of poverty and want (UN, 2015).

Poverty exists historically and relatively as an unwanted element of humanity. It is spatially distributed globally. The Organization for Economic Cooperation and Development (OECD, 2000) studied six countries, including Canada, Germany, Netherlands, Sweden, The United Kingdom and United States and observes that The United Kingdom has the highest poverty at 19 percent followed by The United States with 14 percent. In order to stem the tide of povertydriven global chaos, steady poverty reduction responses from stakeholders seem to have produced some desired results. However, the number of people living on less than $\$ 1.90$ a day fell in 2015 by 68 million to 736 million. Despite the tremendous progress in reducing extreme 
poverty, rates remain stubbornly high in low-income countries and those affected by conflict and political upheaval (World Bank, 2018), a category Nigeria belongs. Over 120 million Nigerians live on less than two dollars a day (Jorge, 2014).

In Maslow's human needs ranking, food, clothing and shelter arguably form the basic requirements, the absence of which is mere existence, comparable with Hobbes brutish state of nature. These should form core governance policy thrusts to avoid conditions that facilitate the growth of social disorder as Nigeria is experiencing presently. Citing Osinbajo, Nigeria's Vice-President, Nwabughiogwu (2015) states that "about 110 million Nigerians still live below poverty line despite the policies of past governments to improve their welfare. This is the main challenge".

The urgency in Osinbajo's concern appears not to have received appropriate response towards improving the situation. Nigeria has successfully reduced its poverty rate by 10 percentage. Poverty rates fell from 46.4 percent in 2004 to 36.2 percent in 2013 . However, this reduction in the poverty rate has not translated into a reduction in the total number of poor citizens. Most Nigerians remain either poor or vulnerable to poverty (Corral, Molini, and Oseni 2015).

A synopsis of the Nigerian agricultural development failure was provided during a visit to the country by the American billionaire, Bill Gates, who delivered truth to the authority, based on a report from a research institute at the University of Washington he commissioned to model Nigeria's economy under three scenarios on health, education and human capital:

Right now, Nigeria fiscal situation is at a low equilibrium. We hope to help you reach a higher equilibrium rooted in effective and transparent investment in people. Better health and education and agriculture will lead to more productive farms and factories. More productive farms will lead to more prosperous farmers who could expand their farms or invest in other businesses, if they had access to credit and other financial tools. These thriving farms, factories and new businesses would lead to more government revenue. And the cycle would start again (Gates, 2018).

Maintaining the status quo on the other hand will continue to reproduce food insecurity, mass migration, civil strife and criminality. Thus, Bill Gates proposition forms the basis of this investigation which, considered along with the Osinbajo's 2015 statement, evaluates the government's agricultural post 2015 policies and programmes. The Osinbajo's statement identifies a salient problem of poverty emanating from poor policies while Bill Gates appropriately offers a solution with emphasis on agriculture. This research is concerned with the consequences of poverty and increasing social disorder which scaling up agricultural practice can vitiate. Agriculture is the basis of Nigeria's rural life which is increasingly becoming the epicenter of socio-economic and ethno-religious conflicts. The research therefore focuses mainly on rural agricultural development and covers the period 2015 to date only.

Against the backdrop of the urgency in revamping Nigeria's agriculture towards turning its fortunes at both the micro and macro levels, the possible research outcomes will identify and fill gaps in the planning, execution, monitoring and evaluation processes that need appropriate official responses. The finding will attempt establishing the extent official intentions align with actions. In particular, the findings will offer the right direction to follow in the effort towards improving food quality and quantity, health and longevity, manufacturing, employment, export and revenue earnings and, very significantly, conflict reduction and social order.

The structure of the research includes introduction as detailed above, brief evaluation of Nigeria's relevant immediate pre 2015 agricultural policies and programmes, evaluation of the 
post 2015 agricultural policies and programmes, productive inputs performance, agricultural production performance, food consumption and prospects for social order, summary and conclusion.

\section{BRIEF EVALUATION OF NIGERIA'S RELEVANT IMMEDIATE PRE 2015 AGRICULTURAL POLICIES AND PROGRAMMES}

Two major government policies, the NV2020 (2009) and the Agricultural Transformation Agenda (2011) profoundly reshaped the county's agricultural environment and practices before 2015. Before 2009, myriad agricultural development policies and programmes were part of the country's development strategies since independence but which generally yielded limited outcomes. Usually rural focused, they include the National Accelerated Food Production Programme (NAFPP), Nigerian Agricultural and Co-operative Bank, Operation Feed Nation (OFN), The Green Revolution Programme, Directorate for Food, Roads and Rural Infrastructure, Peoples Bank of Nigeria, National Agricultural Land Development Authority, National Directorate of Employment (NDE), River Basin Development Authorities (RBDA), Better Life Programme for Rural Women (later renamed Family Economic Advancement Programme) and Petroleum Trust Fund (PTF).

Despite the multiplicity of these programmes, Nigeria has always been poor and food insecure. Dauda (2010) observes: None of these programmes benefitted the rural population but mostly wives and relations of Heads of States, military governors, local government chairmen and others.

In a research on agriculture as a neglected strategy for poverty alleviation in Nigeria, Eze (2003), observes: Target groups, the poor, were hardly reached. These programmes lacked proper linkages with traditional and community leaders at grassroots level. They were meant as benefits to party loyalists, cronies and family relations (Oman, 2004).

The Obasanjo administration since 1999 established rural and agricultural development schemes. Among them were; the Nomadic Education Programme (NEP), Oil Mineral Producing Area Development Commission (OMPADEC), National Poverty Eradication Programme (NAPEP) that includes Youths Empowerment Scheme (YES), Rural Infrastructure Development Service Scheme (RIDSS), National Resources Development Scheme (NRDSN) and National Economic Empowerment and Development Strategy (NEEDS) (2004). NEEDS gave special support to agriculture, industry and small and medium scale enterprises. It targeted protecting the vulnerable groups (rural poor), providing them access to credit and land, participation in decision making, agricultural extension services, improved seeds, farm inputs and implements.

Despite the forgoing efforts, Nigeria is a poor country with food import dependence. Thus, Oxfam International (2017), citing a World Bank Report of 2010 states that Nigeria spends at least N1trillion annually importing rice, sugar, wheat and fish.

In order to escape the food dependency trap, the Federal Government in 2009 established Nigeria Vision 2020 (NV2020), a comprehensive socio-economic transformation agenda for the country with a philosophy that by 2020 , Nigeria would be one of the 20 largest economies in the world. It has two broad objectives: Firstly; to make efficient use of human and natural resources to achieve rapid and economic growth and secondly; to translate the economic growth into equitable social development for all citizens. It planned comprehensive development in all sectors, including agriculture, for example, mapped out specific techniques 
for animal and food production nationwide. It targeted percentage increases in production of cassava, rice local feed, seeds and all possible areas of agriculture.

Due to concerns of ravaging poverty in Africa, in a comprehensive agricultural transformation set of policies to revolutionize agriculture and ensure improved living standards of Africans, in 2014, African Unions (AU) Year of Agriculture and Food Security, the body's Heads of States and Governments adopted the Malabo Declaration on Accelerated Agricultural Growth and Transformation for Shared Prosperity And Improved Livelihood (African Union, Malabo Declaration, 2014). It set parameters on creating enabling environments through institutional reform agenda, targets and measurements that integrates continental, sub-regional and national or country based agricultural policies and programs. The Nigerian government, to some extent, collaborates with this continental agricultural revolutionary initiative and stakeholders with institutional reform programmes on land, funding, fertilizer production and distribution and many others, prominent among which is the Economic Recovery and Growth Plan (ERGP) with the Federal Ministry of Agriculture and Rural Development (FMARD) as the main coordinator.

However, while the economy grew by $7.8 \%$ in 2010, economic growth has slowed and contracted by $1.55 \%$ in 2016 (Proshare (2018). Again, in 2010, Nigeria ranked 153 in its HDI among 188 countries while in 2015, it ranked 152. Being an insignificant improvement, the economy, including agriculture, needs transformation.

The Federal Government's Agricultural Transformation Agenda (ATA) (2011) has six units viz:

(i) Growth Enhancement Support Scheme (GESS) for enhancing access to modern agricultural inputs at subsidized prices by farmers.

(ii) Staple Crop Processing Zone to function on the basis of regional comparative advantages towards production of major crops (cassava, cashew, rice, among others) and livestock.

(iii) Agricultural Commodity Value Chain Development (ACVCD) focusing key crop and animal production.

(iv) Agricultural Marketing and Trade Development Corporations (AMTDCs) to facilitate product marketing.

(v) Agricultural Extension Transformation Agenda (AETA) to enable farmers consume knowledge from extension workers for improved farming and VI Nigerian Incentivebased Risk-Sharing System for Agricultural Lending (NIRSAL), to reduce risks and losses associated with agricultural lending. Additionally is the Youth Employment in Agriculture Programme (YEAP) for food production increase.

A review of the agriculture sector by Olomola and Nwafor (2018) could be summed thus: It appears that access to production factors, inputs and services, remains relatively low in 2016 and progress between 2010 and 2016 has been slow. Potential for improvement in production and productivity is deduced here. If access to inputs and services were doubled, it would have predictable impacts on production, agricultural revenues, consumption and hence peace.

The National Bureau of Statistics (NBS) (2016) report on the economy, in part, states that compared to February 2015, food cost increased 11.3 percent, up from 10.64 in January. It concludes that the economic situation was deplorable with unemployment of 14.4 million at 18.7 percent, consumer prices that jumped to 11.4 percent year -on-year in February 2016, following a 9.6 percent increase the previous month, above market expectations of a 10 percent rise. 
Thus, food insecurity persists even with the ATA, manifesting weak agricultural value-chain and employment capacity.

\section{EVALUATION OF THE POST 2015 AGRICULTURAL POLICIES AND PROGRAMMES}

The Agricultural Promotion Policy (the Green Alternative) of 2016-2020 is the dominant operative document of the post 2015 agricultural environment. The policy thrust and objectives revolve around four themes; food security, import substitution, job creation, and economic diversification.

Its 11 guiding principles are: 1. Agriculture as a business, 2. Agriculture as key to long term economic growth and security, 3. Food as a human right, 4. Value chain approach,5. Prioritizing crops, 6. Market orientation, 7. Climate change and Environmental sustainability, 8. Participation and inclusiveness, 9. Policy integrity, 10. Nutrition sensitivity and 11. Sectorial linkages.

The principles are segregated under three organizing themes viz; APP Productivity Enhancements Crowding in Private Sector Investment FMARD Institutional Realignment.

Table 1: Policy matrix summary

\begin{tabular}{|c|c|c|}
\hline Productivity Enhancements & $\begin{array}{l}\text { Crowding in Private Sector } \\
\text { Investments }\end{array}$ & FMARD Institutional Realignment \\
\hline $\begin{array}{l}\text { 1.Access to land } \\
\text { 2.Soil fertility } \\
\text { 3. Access to information/ knowledge. } \\
\text { 4.Access to inputs } \\
\text { 5. Production management } \\
\text { 6.Storage } \\
\text { 7. Processing. } \\
\text { 8.Marketing }\end{array}$ & $\begin{array}{l}\text { 9.Access to finance } \\
\text { 10.Agribusiness investment } \\
\text { development }\end{array}$ & $\begin{array}{l}\text { 11. Institutional setting and roles } \\
\text { 12. Youth and women } \\
\text { 13. Infrastructure } \\
\text { 14. Climate smart agriculture } \\
\text { 15. Research and innovation } \\
\text { 16. Food consumption and } \\
\text { nutrition security target }\end{array}$ \\
\hline $\begin{array}{l}\text { Target: Blend of metrics including but } \\
\text { not limited to rises in farm } \\
\text { productivity versus base year (\% yield } \\
\text { increases), reductions in post-harvest } \\
\text { losses, share of agricultural input used } \\
\text { in Nigeria by CPG companies, and } \\
\text { share of fresh goods sold in formal } \\
\text { markets e.g. Shoprite. }\end{array}$ & $\begin{array}{l}\text { Target: lower cost of } \\
\text { financing and a greater } \\
\text { availability of such financing } \\
\text { as measured by cost of } \\
\text { capital (\%) paid, number of } \\
\text { loans issued versus overall } \\
\text { credit provision, levels of } \\
\text { private capital formation, } \\
\text { and the number of } \\
\text { participants in the sector. }\end{array}$ & $\begin{array}{l}\text { Target: The target outcome is a } \\
\text { more engaged agribusiness } \\
\text { market space and ecosystem as } \\
\text { measured by ease of doing } \\
\text { business in the sector }\end{array}$ \\
\hline
\end{tabular}

The matrix is organized along the 3 categories: boosting productivity, intensifying role of private investors, and rebuilding the Ministry's capacity to conduct its core regulatory roles. In formulating the policies, the Federal Government (2016) observes:

Recent evidence suggests that overall, the ATA faced challenges such as weak access to credit by smallholder farmers, heavy fiscal burden resulting in sharp rise in indebtedness to banks (especially by agro-dealers who obtained loans from banks to finance input purchase and distribution but who were not paid on time by the government who is responsible for paying 50 percent of what the farmers should pay the agro-dealers...), high post-harvest losses, ... Consequently, Nigeria remains food insecure, relying on food imports worth about $\$ 3.0$ billion to $\$ 5.0$ billion annually, especially wheat, rice, fish, and sundry items, including fresh fruits and vegetables (FMARD, 2016).

These policies try to reverse observed weaknesses into strength. Analysis of few policies will suffice since their elements crisscross others and doing otherwise may mean duplication. 


\section{Land related constraints policy.}

It seeks to ensure access to land in order to attract investments by small, medium and large farmers and processors. The policy provides amending current Land Use Act to facilitate the recognition and entitlement of land ownership by formal or customary means to assist collateralization.

Programmes include taking inventory and log ownership / titles of all land in Nigeria, support reforms to land titling (in States) - support farmer/ land registration (identity, location, landholding; farm size), provide financial institutions links to land title databases

\section{Access to Inputs (various production systems).}

Policy seeks to promote timely availability of good quality inputs for crop production via privately controlled agro-dealer network, ensure approval of the Fertilizer Act; stimulate domestic production of quality fertilizer, and gender balanced targeting of beneficiaries.

Programmes to address: Analyze and address constraints in private sector fertilizer production and distribution systems in agribusiness sector and enhance standards and quality control mechanisms.

Seeds: - Target research to produce relevant crops, increase breeders for key commodities, address shortfalls in seed availability, and enhance standards and quality control mechanisms. Under Animal Production (including livestock, poultry, and small animals), Policy: To regulate grazing / sedentary livestock zones - Improve incentive for feed and fodder industry (including their establishment in Staple Crop processing Zones). Programmes: to stimulate sedentary livestock production by fostering access to land, feed, water and markets; settle nomadic/ pastoral groups and livestock production, enhance availability of improved livestock breeds with higher productivity (milk, meat) and resistance for cows and poultry especially by crossbreeding programs, inputs, pest- and diseases controls.

\section{Access to Finance.}

Policy: Ensuring availability of credit at reasonable conditions for farmers and agribusiness. To facilitate and legislate alternative finance mechanisms e.g. Commodity-trade financing, equipment leasing, etc., promote incentives for commercial and microfinance banks to develop appropriate financial products relevant in rural areas for farmers, women and youth etc., promote inclusive agribusiness development.

Programs: To expand rural access points, reduce need for collateral: Stimulating cooperative banking and affordable loans through commercial banks, microfinance banks and financial NGOs; - recognition of cooperatives and other farming- based organizations financial institutions.

\section{Youth and Women Policy.}

Policy: To review the gender policy document and shifting key behaviors at the institutional level, promote meritocratic entrepreneurial ecosystem to migrate youth and women into service provision roles e.g. fee for service mechanization, agro-dealerships, transform rural quality of life.

Programmes: Government to partner with private companies to expand rural modern conveniences e.g. movie theaters, shopping malls, etc., build capacity of women and youths in entrepreneurship, including support to entrepreneurial ventures, technical training, enhance 
access to financial services, land (Policy thrust 1) focusing women and youth rights, access to finance (Policy Thrust 10) with a focus on women and youth rights.

\section{Storage. Policy:}

To enforce standards in quality of storage facilities: enforcement of minimum moisture content for stored food, promotion of the use of alternative pest control in storage and safe use of pesticide and agrochemicals. Programmes: To research on key storage constraints, enhance access to improved storage facilities.

\section{Food, Consumption and Nutrition Security Policy:}

To promote sustainable agriculture and food systems to improve freshness and quality of Nigerian food intake - set nutrition standards to reduce increasing cases of diabetes and obesity, promote private management of the grain reserve silos.

Programmes: To address national food and nutrition security, measures under Policy Thrust 19 above, review silos project and other levels of storage to meeting the goal of $5 \%$ grain in storage, maintaining strategic reserves to make food available at short notice and for stabilizing food prices; maintain safe storage (food security for a minimum of 1 year), enhancing cooling and cold chain, processing and packaging of nutritious food. Reduce risk of contaminated foods by proper testing.

\section{PRODUCTIVE INPUTS PERFORMANCE}

The drive for agricultural revolution in Nigeria is mainly government driven as outlined in the foregoing provisions. It is expected that growing Nigeria's agricultural production is a function of the level of productive inputs. Nigeria's official success is identified and evaluated below. 
Okwuwa, C. O. (2019). Evaluation of Bill Gate's panacea for development and poverty reduction in Nigeria through improving agriculture. Advances in Social Sciences Research Journal, 6(5) 201-216.

Table 2: Production factors, inputs and services for agriculture sector activities

Indicator Vision 2020 Target

\begin{tabular}{|c|c|c|c|c|c|c|c|c|}
\hline Indicator & Vision 2020 Target & 2010 & 2011 & 2012 & 2013 & 2014 & 2015 & 2016 \\
\hline $\begin{array}{l}\text { Proportion of farm } \\
\text { households with } \\
\text { insecure land rights } \\
\text { (used free of charge) }\end{array}$ & Malabo: 0 percent by 2025 & & 10.4 & & 12.9 & & & 7.9 \\
\hline $\begin{array}{l}\text { percent of plots on } \\
\text { which purchased } \\
\text { seeds were planted }\end{array}$ & $\begin{array}{l}\text { Vision: } 50 \text { percent (2015); } 75 \\
\text { percent (2020) Malabo: } 100 \\
\text { percent increase } 2025 / 2015=\end{array}$ & & 26.1 & & 21.3 & & & 22.9 \\
\hline $\begin{array}{l}\text { Percentage of deposit } \\
\text { money bank loans } \\
\text { advanced to the } \\
\text { agriculture sector }\end{array}$ & $\begin{array}{l}\text { EGRP/APP: } 10 \text { percent by } \\
2017 / 8\end{array}$ & 1.7 & 2.6 & 3.7 & 3.9 & 3.6 & 3.6 & 3.3 \\
\hline $\begin{array}{l}\text { Loans by deposit } \\
\text { money banks to } \\
\text { agriculture (trillions) }\end{array}$ & & 1.8 & 2.3 & 3.4 & 4.1 & 4.8 & 5.6 & 5.9 \\
\hline $\begin{array}{l}\text { Proportion of men } \\
\text { and women with } \\
\text { access to financial } \\
\text { services }\end{array}$ & $\begin{array}{l}\text { Vision: } 80 \text { percent by } 2020 \\
\text { Malabo: } 100 \text { percent by } 2025\end{array}$ & & & & & & & \\
\hline All Nigeria & & 54.0 & & 60.3 & & 60.5 & & 58.4 \\
\hline Rural & & & & & & 52.2 & & 47.8 \\
\hline Urban & & & & & & 75.2 & & 75.6 \\
\hline Male & & & & 63.9 & & 64.2 & & 63.2 \\
\hline Female & & & & 56.5 & & 57.3 & & 53.4 \\
\hline $\begin{array}{l}\text { Fertilizer } \\
\text { consumption } \\
\text { (kilogram of } \\
\text { nutrients per hectare } \\
\text { of arable land) }\end{array}$ & $\begin{array}{l}\text { Vision and Malabo: } 50 \mathrm{~kg} / \mathrm{ha} \text { by } \\
2015 \text { or } 2025\end{array}$ & 12.76 & 6.78 & 11.99 & 14.32 & 9.38 & 8.89 & 13.55 \\
\hline $\begin{array}{l}\text { percent of cultivated } \\
\text { plots fertilizer was } \\
\text { used on }\end{array}$ & & & 38.00 & & 38.00 & & & 47.30 \\
\hline $\begin{array}{l}\text { percent of cultivated } \\
\text { plots herbicides were } \\
\text { used on }\end{array}$ & & & 22.00 & & 24.80 & & & 30.50 \\
\hline $\begin{array}{l}\text { percent of cultivated } \\
\text { plots pesticides were } \\
\text { used on }\end{array}$ & & & 14.00 & & 15.40 & & & 20.70 \\
\hline $\begin{array}{l}\text { percent of plots } \\
\text { which were irrigated }\end{array}$ & $\begin{array}{l}\text { V: } 10 \text { percent by } 2015 \text { and } 25 \\
\text { percent by } 2020 \text { (of cultivated } \\
\text { land); Malabo: } 100 \text { percent } \\
\text { usage increase } 2000-2025 ; \\
\text { ERGP: }+100,000 \text { irrigable land } \\
\text { by } 2020\end{array}$ & & 3 & & 1.60 & & & 1.70 \\
\hline $\begin{array}{l}\text { Percentage of } \\
\text { households that } \\
\text { participated in } \\
\text { extension activities }\end{array}$ & $\begin{array}{l}\text { Vision: } 1: 500 \text { by } 2020 ; \text { Malabo: } \\
100 \text { percent access by } 2025 ; \\
\text { EGRP - 1:1000 by } 2020\end{array}$ & & 10 & & 9.8 & & & 13.7 \\
\hline
\end{tabular}

\section{Source: Central Bank of Nigeria, National Bureau of Statistics (2011, 2013 and 2016) and EFINA}

One of the indicators that measure production factors is the proportion of farm households with insecure land rights (used free of charge with a Malabo target of zeroing the figure by 2025). The figures which stood at 10.4 and 12.9 in 2011 and 2013 respectively decreased to a 
success level of 7.9 in 2016. The percent of plots on which purchased seeds were planted had NV 2030 target of 50 by 2015, 75 percent by 2020 and a Malabo target of 100 between 2015 and 2025. However, by 2016, achievement level was only 22.9 percent. This is a major challenge in agricultural innovation efforts in Nigeria since hi-breed seeds largely produce high yields.

A major challenge in agriculture is funding. There was a steady rise on percentage of deposit money bank loans advanced to the agricultural sector judging with the ERGP and Agricultural Promotion Policy targets of 10 percent by 2017 and 2018 from 1.7\%, 2.6\%, 3.7\% and 3.9\% in 2010, 2011, 2012 and 2013 respectively. However, the figure fell to 3.6\%, 3.6\% and finally $3.3 \%$ percent in 2014, 2015 and 2016 respectively. Loans by deposit money recorded a steady rise from $1.8 \%$ in 2010 to 5.9 in 2016 towards a 10\% target. The national proportion of men and women with access to business financial services declined from 2014 (60.5) to 58.4 in 2016. In terms of spatial location, the urban areas was favored with $75.2 \%$ more than rural areas (52.2\%) in 2014. By 2016, the downward trend continued; urban share was 75.6 percent while rural share was $47.8 \%$. This suggests continuation of rural neglect that perpetuates poverty, Nigeria's present experience.

A disfavored gendered feature of the political economy is manifest in access to financial services. Males recorded 63.9 percent and females 56.5 percent in 2012, 64.2 and 57.3 in 2014 and 63.2 and 53.4 percent in 2016 respectively. Financial inclusion in Nigeria at $58.4 \%$ remains behind the target of $70 \%$ by 2020 , and low compared to $87 \%$ South Africa and 82.65 in Kenya (Uzor, 2017). Financial inclusion facilitates businesses, entrepreneurship and expansion and can be executed by small holder farmers and small scale famers. When these categories are included, they expand the agricultural value chain, create job opportunities, reduce unemployment and poverty and importantly rural-urban migration and criminality.

There was however an improvement on the percent of cultivated plots fertilizer was used on, 47.30 percent in 2016 from 38.00 in 2014. Likewise, there was an improvement on the cultivated plot from 24.80 to 30.50 percent in 2013 and 2016 respectively. The use of herbicides increased from 15.40 in 2013 to 20.70 percent in 2016. Area of irrigation suffered the worst setback as achievement levels of 3 percent for 2011, 1.6 percent for 2013 and 1.7 percent for 2015, are far less than the lowest target of 10 percent for 2015 and 25 percent in 2020 for NV2020.

The input level on percentage of households' participation in extension services was modest; the performance recorded a very marginal and insignificant increase, 10 percent, 9.8 percent and 13.7 percent in 2011, 2013 and 2016 respectively. The 13.7 percent 2016 record is insignificant considering the targets (NV: 500; Malabo 1:100 percent access by 2025 and ERGP 1:1000 by 2020). This is important because farmers' relevant modern farming knowledge is the key to agricultural success.

On storage, in reality, the value of tomatoes being harvested in Nigeria annually is about 1.8 million tons with about 700 tons being lost due to lack of storage and processing facilities during post-harvest (African News, 2018). Storage is a major setback in Nigeria's agriculture. Tomatoes, mangoes and all perishable fruits and vegetables face storage challenges and hence negative impacts on health and nutrition, revenue and family welfare.

Youths and women have not fared very well in the agricultural value chain. Policy statement to modernize rural areas with amenities, theatres, recreational facilities infrastructure like roads, electricity and water was not been met. Women participation in the Government Enterprise 
Empowerment Programme has been remarkable with 56\% of loans disbursed to them in 28 states and the FCT (Kolawole, 2017), quoting the federal government. This however, from forgoing data is skewed in favor of males. Gender balance advocacy in Nigeria is in ascendency and may narrow the gap in the near future.

\section{AGRICULTURAL PRODUCTION PERFORMANCE}

Throughout 2016, agriculture was the highest growth sector (4.54\% for all four quarters). In 2017, (3.4\% in Q1) and (3\% in Q2), overall, the sector grew to $12.5 \%$ compared to 9.8\% in Q1, 2016. However, there was a record of slight slowdown in the sector particularly in the crop sector $(3.2 \%$ 2017), against 3.5\% (Q1, 2016). Crop production remains the main driver of the sector. This is evident as it accounts for $91.97 \%$ to nominal GDP (GDP Report, (Q4 and Full Year).

Agriculture's annual contribution to GDP for 2017 was $25.08 \%$ and $24.45 \%$ for 2016 (NBS, 2018). In essence, agricultural production and hence contribution to the nations GDP from 2016 to 2017 was negligible. Data from the CBN and FAO (2017) indicate that services account for $53 \%$, manufacturing $21 \%$ with agriculture accounting for $20 \%$.

When measured by key indicator(including agricultural production), the economy hits its seemingly lowest ebb in two decades by the close of 2015 , and was further dragged down during the first quarter 2016 by issues of economic policies, aspects of production and distribution of agricultural product, among others. Overall, agriculture growth rate declined from 4.19 percent in 2011-2013 to 4.03 percent between 2014 and 2016 (Central Bank of Nigeria) (CBN) (2017). Correspondingly, Zenith Economic Quarterly (2016) concludes that the Nigerian economy recorded a somewhat weak performance in major indicators in the first quarter of 2016. However, the NBS (2017) reported that Nigeria experienced growth (0.55) in Q2 (2017), after five consecutive quarters of contraction, and facilitated by agriculture, oil, manufacturing and trade. Growth itself does not reduce mass poverty, but rather, the distribution of the commonwealth, the subject discussed below.

\section{Food consumption and prospects for social order}

Food quality has decreased as data indicate that undernourishment increased from $6.1 \%$ in 2010 representing 9.7 million people to $7 \%$ in 2016, representing 12.9 million. The pangs of hunger and lack of nutritional derivatives of efficient farming abound. Nigeria's large GDP growth has not kept pace with the country's reduction in poverty; for every 1 percent growth in GDP per capita, the country experienced only a 0.6 percent decline in poverty (Oxfam International, 2017) citing Molini (2016). Inequality is increasing in terms of income, food and general consumption. The observed share of the $1^{\text {st }}$ quartile or 25 percent of the population in national consumption (food and income) in the preceding section was 5.4 percent in 2010 . Ideally, the expected $1^{\text {st }}$ quartile share should be 25 percent. Nigeria was one of the countries that experienced the worst food crisis in the world in 2018 (UN, EU, 2019).The worst food crisis in 2018, in order of severity were: Yemen, DR Congo, Afghanistan, Ethiopia, Syria, Sudan, South Sudan and Northern Nigeria...A short-term outlook of food insecurity showed that Nigeria will remain among the world's most severe cases of food crisis, same as the other seven, the report indicates.

This falls short of Nigeria's agricultural improvement initiatives for food security and people's better living standard. Income, food and consumption inequality are linked with unemployment and reflect a country's human development index. 
During the post APP review period, unemployment has been rising in Nigeria; $7.8 \%, 10.2 \%$ and $14.2 \%$ for 2014, 2015 and 2016 respectively (NBS, 2016). The latest 2018 unemployment figure is $23 \%$ (NBS, 2019). This suggests that the economy, with agriculture as the most visible sector, needs serious attention towards meeting set targets. The ILO (2016) reports that 197 million people globally were unemployed and forecast a 200.5 million record by 2017, the highest in history. It states further that $60-70 \%$ of the figure would be mostly youths from developing, emerging and low income countries, a category that Nigeria belongs.

A general practice of evaluating a country's development is the computation of measures of national achievements in human development in three critical areas of life; health, education and income or living standards reports. The UNDP (2018) states that Nigeria's Human Development Index (HDI) for 2017 was .532 out of 187 countries sampled, and thus moved two points from the 2016 score of .530. It concludes however, that Nigeria's ranking did not change from $157^{\text {th }}$ out of the 189 countries sampled. This finding underpins the reality that while economic growth is critical for poverty reduction, it is not sufficient. Mass life experiences are the concern.

Human development entails promoting the freedom of all individuals and groups, including the poor. That is why agricultural developmental efforts should holistically focus equity, on commercial, small stakeholder and subsistence farmers, both rural and urban, and youths, with gender balance. Efforts should not be operated as elitist and narrow approaches that symbolize exclusion as practiced in Nigeria where the female gender, youths, and rural agriculture are disfavored in relation to gender and spatial locations as suggested by the foregoing statistics. The poor rural virtually feed the nation, but operate in hardship and exclusion.

Agriculture nourishes Nigeria and supports half of the population, especially the poor... It has a large potential to grow. But majority of Nigerian smallholder farmers lack access to the seeds, fertilizer and training they need to be more productive. They lack access to good roads.... One of the barriers that continues to prevent smallholders from thriving is lack of access to finance. Finance connects farmers to opportunity, yet only 4 percent of Nigerian framers access loans to growth their business... (Gates, 2017).

The teeming Nigerian youths, the rural dwellers, female gender and others living on the fringes of life need inclusion in the agricultural and socio-economic spaces. They have potentials for development with the right opportunities. With equity in sharing the commonwealth, perhaps, Nigeria's 23 percent unemployment rate for 2018 could have been in a lower digit. The effects of poverty are high on women and youth. Solving the problem of poverty has to focus on inclusive programmes that will impact the life of the two groups. Women and youth pass through emotional, mental and behavioral trauma with poverty (Yoshikawa, Aber and Beardslee, 2012).

Many developing countries have had difficulty diffusing the benefits of rapid growth and industrialization wide enough to satisfy rising social expectations. In rich and poor countries alike, social exclusion is a burning political issue (World Economic Forum, 2017). It is socially designed. In a research on poverty in Nigeria, Okwuwa (2014) opines that dearth of managerial expertise and policy mal-alignment, several poverty alleviation interventions, many of them well diagnosed, were hoisted on a predominantly agrarian economy immensed in mass illiteracy, ethnocentric sentiments and anti-development and culturally rooted practices. From extant data with generally low agricultural input (notably finance, extension services knowledge and information) and output indices, governance in Nigeria could be described as 
elitist and hence exclusive. Mass illiteracy is antidevelopment as it lacks the basic people empowerment catalyst.

Nigeria should invest in its people. Healthy people need opportunities to thrive. One of the most important of these opportunities is agriculture. What becomes of that potential dependents on choices leaders make? The most important choice is to maximize your greatest resource, the Nigerian people. Nigeria will thrive when every Nigerian is able to thrive (Gates, 2017). The gale of ethno-religious conflicts today are fueled by vastly negative socio-economic indicators, resulting from exclusive policy 'leadership choices'. The choices manifest impunity, political-cum-ethno religious interest mix, clannishness, institutional weakness, gender bias and others. They vitiate agriculture and general national development. Countries need to continue with structural reforms, vital to accelerating the sustainable and inclusive growth needed to end extreme poverty by 2030 . We have to find new and innovative ways to reach the poor and make the world more secure and stable (Kim, 2017), President of the World Bank.

Thus, from data, quality of life in Nigeria is low. This cycle of poverty keeps progressing while governance continues reproducing more poverty and social tension which are manifest in all forms of conflicts, kidnappings and political thuggery. A situation that compels the presidential candidates to sign peace undertakings for the 2019 elections, like the case in 2015, among other considerations, prefigures the availability of an army of the unemployed as willing tools, poor, hungry children and youths. The category is political thuggery versed, being gainfully unemployed and seeking survival. They do so because of poverty. The marginalized children and youths, and their parents could have been effectively integrated into the socio-economic and political systems, in the Talcott Parsons sense, if the economy had been more developed, and that, through a robust agriculture that feeds and nourishes the population and manufacturing with raw materials and high revenue yielding export earnings. It equates deficit leadership choices in the contest of existing opportunities of which Nigeria is blessed with human and natural resources.

\section{SUMMARY AND RECOMMENDATIONS}

This study evaluates the Buhari government's agricultural inputs performance, level of agricultural production, living standards in line with above APP's four focal points, in alignment with the Bill Gates panacea for poverty reduction through agriculture.

Economies develop as a historical necessity, with improvements in agricultural production. Nigeria has been an agrarian society on which majority of the population derive employment and food. Nigeria's various agricultural improvement policies have not made any meaningful impact. Nigeria is poor country with food dependence on imports. Thus, Oxfam International (2017), citing a World Bank Report of 2010 states that Nigeria spends at least N1 trillion annually importing rice, sugar, wheat and fish. From 2009, two major government initiatives, the 2009 NV2020 and the Agricultural Transformation Agenda (2011) were established to radically reshape the agricultural environment and practices before the Buhari administration. From data, Nigeria lacks visibility in global and national agricultural innovation.

The proportion of farm households with insecure land rights may not meet the 10 percent Malabo target of zeroing the figure by 2025 with records which stood at 10.4 and 12.9 in 2011 and 2013 respectively decreased to 7.9 in 2016. Further, the percent of plots on which purchased seeds were planted had NV 2030 target of 50 by 2015, 75 percent by 2020 and a Malabo target of 100 between 2015 and 2025 but by 2016, the only available data was 22.9 percent target. The two land related challenges need to be adequately addressed to achieve desired targets. 
The of percentage of deposit money bank loans advanced to the agricultural sector based on the ERGP and Agricultural Promotion Policy targets of 10 percent by 2017 fell; $3.6 \%, 3.6 \%$ and finally $3.3 \%$ percent in 2014, 2015 and 2016 respectively. Previously, the impressive upward trend was $1.7 \%, 2.6 \%, 3.7 \%$ and $3.9 \%$ in 2010, 2011, 2012 and 2013.

On end users, the proportion of men and women with access to financial services declined from 2014 (60.5) to 58.4 in 2016. Spatially, the urban areas were favored with $75.2 \%$ more than rural areas with only 52.2 percent in 2014. By 2016, the urban share was virtually unchanged at 75.6 percent while rural share declined at $47.8 \%$, a factor that perpetuates rural neglect and poverty. The gendered access to financial services reveals that males and females received 63.9 percent and 56.5 percent in 2012, 64.2 and 57.3 in 2014 and 63.2 and 53.4 percent in 2016 respectively. Thus, the situation of females who constitute very significant agricultural labor force in Nigeria worsened within the period, according to data. Women undertake 60 to $90 \%$ of the rural marketing; but do not have access or control over land and other productive resources (Agro Nigeria, 2016). In effect, much efforts are needed to meet set targets. Financial inclusion facilitates entrepreneurship and business expansion by small holder farmers and small scale farmers. When included, these categories can expand the agricultural value chain, create job opportunities, reduce unemployment and poverty, and importantly, rural-urban migration and criminality.

The percentage use of fertilizer and herbicides on cultivated plots increased, likewise improvement on the cultivated plots in 2013 and 2016. Herbicide use increase is vital for enhanced farm yields and lose reduction associated with disease attacks. This could be most relevant particularly in the pest infested very humid and swampy equatorial belts. However, use of irrigation suffered the worst setback as achievement levels of 3 percent for 2011, 1.6 percent for 2013 and 1.7 percent for 2015, are far less than the lowest target of 10 percent for 2015 and 25 percent in 2020 for NV2020. The 2015 figure suggests that the desired 10 percent target can hardly be met by 2020 . The challenge deserves urgent attention in taking cognizance of the disturbing climate change desertification effects in Nigeria such as forced massed north south migration, herders cum farmers conflicts and bloody ethno-religious polarized relationships.

Equally disturbing is the insignificant percentage increase of households' participation in extension services (10 percent, 9.8 percent and 13.7 percent in 2011, 2013 and 2016 respectively, against set higher targets. The challenge here is that rural farmers continue practicing traditional agriculture with low yields, lacking modern farming techniques. If Nigeria can achieve only 13.7 percent in 2016 from a set target of one extension worker to five hundred households in 2020, the situation calls for concern. This collaborates Olomola and Nwafor (2018): Food quality has decreased as data indicate that undernourishment increased from $6.1 \%$ in 2010 representing 9.7 million people to $7 \%$ in 2016, representing 12.9 million. The pangs of hunger may worsen.

Consequently, the followings recommendations are made:

1. Inclusiveness in resources allocation for all genders and locations (funds of all classes, fertilizers, herbicides, processing and storage facilities), both urban and rural at the policy and implementation levels.

2. Grassroots economic revolution (infrastructure, leisure facilities, modern farms, finance) to integrate rural dwellers and economy with apparently elitist and urban affluence.

3. At least, 10 percent budget allocation to Agriculture as per Malabo Declaration (2014). 
4. Extension services penetration particularly to the rural areas to meet theft Vision: 1: 500 by 2020; Malabo: 100 percent access by 2025, EGRP - 1:1000 by 2020 all of which the APP relies on to meet its objectives. This is very important because extension survives convert technology adaptation, knowledge transfer, higher production and productivity.

5. Radical social inequality reduction to enable very low income earners meet their basic needs in Abraham Maslow's conception. Food is a basic necessity and human right the absence of which generates frustration and criminal tendencies. Nigeria's minimum wage of $\mathrm{N} 18,000(\$ 50)$ per month, for the few wage earners (Nigeria's majority do not earn regular wages and some operate in the unpredictable informal sector), promote social inequality, which facilitated making Nigeria the world poverty capital.

6. Land ownership reforms including documentation, gender rights, along with improved rural economic landscape to reverse the push and pull factor towards youth and female involvement in agriculture and hence food security.

7. Climate change induced migration by herders and low class individuals who practice farming as a single or dual occupation need being addressed principally by improving irrigation services in northern Nigeria to enhance food and raw materials availability and reduced ethnic and communal conflicts most of which are land ownership related.

\section{CONCLUSION}

Nigeria's agricultural related policies and programmes trend of failures tend to question the sincerity of leadership. Aptly, Bill Gates addressed this phenomenon by speaking truth to the authorities to lift the standard of living of Nigerians. The Nigerian case is most intriguing because it has such an agriculture friendly climate and vegetation that would manifestly support agricultural breakthroughs of not just food security but also high revenue through export earnings, industrialization, employment generation and poverty reduction. With the AGOA export window and stream of oil revenue in a dwindling industry, technology driven agriculture in Nigeria would lift Nigeria's living standard. It would deliver the benefits advanced by Bill Gates in 2018:

Better health, education and agriculture will lead to productive farms and factories, hence more prosperous farmers who could expand their farms or invest in other businesses, with access to credit and other financial tools. The thriving farms, factories and new businesses would lead to more government revenue. And the cycle would start again.

Human resource is the most important of all productive factors. Wealth emerges from the experimental interaction between humanity and the environment, specifically natural resources. Wealth enhancing land and knowledge powered human beings are the main resources that leadership must improve in an inclusive mix. Land is a natural gift and whatever challenges arising from its usage (ownership titles, gender issues, among others) are human creations promoting exclusive interests. Humanity is a resource without birth purchase price but only attracts empowerment value addition costs, expended through education and training. With right diagnosis and political will, Nigeria can achieve food security, industrialization and high human development index to address the Bill Gates well diagnosed concerns that can elevate it from a near Thomas Hobbes state of nature to a modern state of abundance and peace.

Nigeria has a rich arable land and population for bumper food production, with the possibility of producing more than Brazil (Christensen, 2018). If political will permits, this is possible, otherwise, Nigeria will continue on the present pedestrian slow socio-economic development 
and high poverty, crime and conflict growth. Government should empower Nigerian's to unleash their potentials. Gates (2018) has offered the panacea:

The most important choice is to maximize your greatest resource, the Nigerian people. Nigeria will thrive when every Nigerian is able to thrive. Nigeria should invest in its people. The data backed summary and recommendation support Bill Gates. Nigeria is now the biggest economy on the continent with unmatched economic potentials and yet the 2018 world's poverty capital. Oguyne (2019), a renowned agricultural economist has also opined: Government should implement policies that favor farmers which must emphasis microfinance, land reforms and adaptable technology.

\section{References}

African News (2018). Advertorial (2018) Storage.httsp: www.africannewsage.net .Retrieved 3/1/2019.

African Union, Malabo Declaration, www.fao.org). Retrieved 15/12/2018.

Agro Nigeria (2016)). Role of women in Agriculture, https:www.agronigeria.com.ng/role-women-.agriculture. Retrieved 12/4/2018.

CBN (2017). Real sector statistics. Ststistics.cbn.gov.ng/cbn-onlinestats/Data Browser.aspx

Christensen, P. (2018). Nigeria Can Produce More Food than Brazil, speech delivered at a One-Day Danish Food Tech Exhibition and Seminar, 28 ${ }^{\text {th }}$ September. Vanguardnig.com. Retrieved $4^{\text {th }}$ January, 2018.

Corral, P., V. Molini, V. and Oseni, G. (2015). "No Condition is Permanent: Middle Class in Nigeria in the Last Decade." Policy Research Working Paper 7214, World Bank, Washington, DC.

Dauda, Y. O. (2010). Rural Development in A Decade of Return to Democracy, 1999-2000, (Ed.)

Egwemi V. A. Decade of Democracy in Nigeria, 1999-2009, Issues, Challenges and Prospects of Consolidation, Abuja: Aboki Publishers.

Eze, P. (2003). Sustainable Environment: A Neglected Strategy for Poverty Alleviation in Nigeria In Onakaka et al (eds.) Environment and Poverty in Nigeria, Enugu: JAMOE.

FGN (2016). Agricultural Promotional Policy 2016-2020 FMARD, Abuja: FMARD.

FMARD (2016). The Agricultural Promotion Policy, (2016-2020), Building on The successes of the ATA, Closing Key Gaps, Policy and Strategy Document, Abuja: FMARD.

FRN (2011). Agricultural Transformation Agency, Abuja: Gates, B. (2018). Speech by Bill Gates, Co-Chair of Bill and Melinda Gates Foundation at the National Economic Council, Aso Rock Villa, Abuja, 22 March, 2018 In Daily Trust, 22 March, 2018, https://dailytrust.com.ng. Retrieved 12th January, 2019

ILO (2016). World Employment and Social Outlook Trends in 2016 www.ilo.org

Jorge, S. (2014). Over 120 million Nigerians live on less than two Dollars per day. Vanguard, 15 July, p.1.

Kim, Y. J. (2017). World Bank Pledges Strong Support For Nigeria's Fight Against Famine, speech at the World Bank/IMF Spring meetings in Washington, 21/4/2017.

Kolawole, Y. (2017). FG disburses N7.3 billion for Enterprise Empowerment, Vanguard, 25 June.

National Bureau of Statistics (2016). LSM-Integrated Survey of Agriculture General Household Survey Panel 20152016, Abuja: NBS.

National Bureau of Statistics (NBS) (2017). Report Q2, 2017, NBS, Abuja.africanharvesters.com

National Bureau of Statistics (NBS) (2018). Nigerian Gross Domestic Product Report, 2017, NBS, Abuja.

National Bureau of Statistics (2019). 2018 Agriculture Report,htps://africanharvesters.com

NEEDS (2004). National Economic Empowerment and Development Strategies (NEEDS) (2004), Abuja: National Planning Commission.

Nigeria Vision 2020 https://www.nv2020.org/ Retrieved 3/7/2018.

Nwabughiogwu, L. (2015). Over 100m Nigerians living below poverty line - Osinbajo. August 20, 2015, at a courtesy visit by members of the Alumni Association, National Institute for Policy and Strategic Studies (NIPPS),

State House, Abuja. 
OECD (2000). 2nd OECD Conference on Women Entrepreneurs in SMEs: Realizing the Benefits Of Globalization and the Knowledge-Based Economy, Paris, 29th $-30^{\text {th }}$ November, 2000.

Ogunye, B. (2019).Government should implement policies that favor farmers, guest speaker, Channels Television discussion, 17th January.

Okwuwa, C.O. (2014). Poverty and Childhood Experiences in Nigeria, A Sociological Analysis in Lapai Journal of Sociology, Vol. 5, No.1, Pp. 35-48.

Olomora, A. S. and Nwafor, M. (2018). Agricultural Sector Performance Review. Ibadan: NISER.

Omah, C. (2004). Poverty in Nigeria Post- Military Era: A Case Study of the Obasanjo Administration (1999-2003). An Unpublished Seminar paper, University of Nigeria, Nsukka.

Opurum, K. (2018). 2018 Outlook for Nigeria's Agricultural Sector, leadership.ng retrieved 27/12/2018.

Oxfam International (2017). Inequality in Nigeria, exploring the derivers, Oxfam in Nigeria, www.oxfam.org

Proshare (2018). Nigeria's Vision 20:2020: Review and Prospects With Two Years to Go, https://www.proshareng.com

UN (2015). Transforming our world: The 2030 Agenda for sustainable development. A/RES/70/1

UN (2019). Nigeria among the world's hungriest people in 2018, UN Report.www.pulse.ng

UNDP (2016). Human Development Report http://hdinigeria.org

UNDP (2018). Human Development Report http://hdinigeria.org

Uzor, S. E. (2017. Financial Inclusion in Nigeria: The Untapped Opportunities in Zenith Economic Quarterly, Vol. 13, No. 3, Pp.28-34.

WEF (2017). The Inclusive Growth and Development Report (2017). WEF_IncGrwth_2017.pdf

World Bank (2018). Decline of Extreme Poverty continues but has slowed, Press release, Sept.19.

World Bank Group (2017). WASH Poverty Diagnostics, www.worldbank.org

Yoshikawa, H. Aber, J. L.; and Beardslee, W. R. (2012). The Effects of Poverty on Mental,

Emotional, and Behavioral Health of Children and Youths; Implications for Prevention https//www.coursehero.com.

Zenith Economic Quarterly (2016). Facts and Figures, Vol 12, No. 2, April, 2016, P.78. 